\author{
Mar/2020 \\ Working Paper 20-11 \\ rcea.org/RePEc/pdf/wp20-11.pdf
}

\title{
FAR RIGHT, EXTREME LEFT AND UNEMPLOYMENT: A EUROPEAN HISTORICAL PERSPECTIVE
}

\author{
Theodore Panagiotidis \\ University of Macedonia, Greece \\ RCEA
}

Costas Roumanias

Athens University of Economics and Business, Greece

Copyright belongs to the author. Short sections of the text, not exceeding three paragraphs, can be used provided proper acknowledgement is given.

The Rimini Centre for Economic Analysis (RCEA) was established in March 2007. RCEA is a private, nonprofit organization dedicated to independent research in Applied and Theoretical Economics and related fields. RCEA organizes seminars and workshops, sponsors a general interest journal, the Review of Economic Analysis (REA), and organizes a biennial conference, the Rimini Conference in Economics and Finance (RCEF). Scientific work contributed by the RCEA Scholars is published in the RCEA Working Paper series.

The views expressed in this paper are those of the authors. No responsibility for them should be attributed to the Rimini Centre for Economic Analysis. 


\title{
Far right, extreme left and unemployment: a European historical perspective
}

\author{
Theodore Panagiotidis \\ Department of Economics, \\ University of Macedonia, \\ Thessaloniki, Greece \\ tpanag@uom.gr
}

\author{
Costas Roumanias, \\ Athens University \\ of Economics and Business, \\ Athens, Greece \\ roumanias@aueb.gr
}

March 2020

\begin{abstract}
We examine the long run relationship between European far right, radical left and unemployment. A unique dataset is compiled for 31 European countries that span from 1900 to 2013. We reveal the long-run relationship between extreme right and unemployment. An increase in unemployment and radical left increases the far-right vote share.
\end{abstract}

JEL C21, N14

Keywords: extreme right, extreme left, unemployment rate, cointegration 


\section{Introduction}

The upsurge in the European far right vote shares experienced after the early 1980's has renewed popular and scholarly interest in the determinants of radical voting. Crises and economic insecurity are among the most prominent factors that lead to radical voting. For example, Funke et al. (2016) show a long-run relationship between financial crises and extreme (both left and right) voting. Unemployment has been pivotal in the debate on the determinants of the far-right vote. It is cited consistently as the main cause leading to political extremism in elections from the Weimar Republic to contemporary Europe alike.

Empirical studies have invariably tested the effect of unemployment on both individual and aggregate levels (Golder 2003, Arzheimer 2009, Arzheimer and Carter 2006). The results are not unequivocal. A number of studies find a positive relationship between unemployment and the far-right vote, some negative and some find no statistical significance (for an overview see Mudde 2007 and more recently Georgiadou et al 2018). ${ }^{1}$ Although there is evidence of a relation between radical left and the extreme right (Bustikova 2014), to the best of our knowledge their long-run relationship has not been explored.

We revisit the relationship between (i) far right vote and unemployment and (ii) far right, radical left and unemployment employing a unique dataset containing 31 European countries, with electoral data going back to the beginning of the $20^{\text {th }}$ century. We cover essentially all European elections both geographically and temporally, offering a complete investigation of the long-run relationship between unemployment and far right.

We reveal a long-run (cointegrating) relationship between the aggregate European far right and radical left vote shares and average, population-weighted, unemployment. We find that (i) a long-run relationship exists between far right and unemployment, (ii) a 1\% rise in the average European unemployment rate implies a $1.37 \%$ rise in the overall support for the European far right (that is support for both extreme right parties and the more moderate radical right parties) and (iii) both unemployment rate and radical left affect positively far right. The evidence for the relationship between unemployment and radical left is weaker.

\footnotetext{
1 Matakos and Xefteris (2017) argue that when the economy is not in turmoil there is a positive relationship between (relative small changes in) unemployment and support for systemic parties. They could not exclude the possibility of a negative relationship from a theoretical point of view.
} 


\section{Data}

Electoral data were obtained by Mackie and Rose (1995), Nohlen and Stöver (2010) and the European Elections Database (EED). Data on unemployment were collected from various sources as described in detail in the online Appendix.

For the identification of radical left and far right parties, we followed Payne (1995), Ignazi (2002), Golder (2003), Minkenberg (2013), Mudde (2007) and March (2011) as described in the online Appendix. We categorize radical left and right parties in terms of extremity as follows: (populist) radical right refers to Mudde's (2007) category of nativist parties with authoritarian ideology or practice. Extreme right adds anti-democratic stands and is the most extreme example of right-wing radicalism. Far right refers to all radical and extreme right parties as an encompassing category. Following March (2011), the left is divided by degree of extremism to the radical left and the extreme left. Our approach is a time series one as we aggregate all variables at the European level by taking population-weighted averages. ${ }^{2}$

\section{Discussion}

Figure 1 plots the European far-right vote share and the population-weighted European unemployment rate between 1900 and 2012.3 The two series move together, indicating a potential long-run relationship.

We start our analysis with unit root and stationarity tests (with and without breaks, all available in an online appendix). ${ }^{4}$ The results point towards non-stationarity for all the variables under investigation and 1933 emerges as the most important break in most of the cases. The next step would be to employ cointegration tests to examine whether there is a long-run relationship between far right (extreme and populist), radical left (extreme and populist) and unemployment. All possible pairs with unemployment were considered.

We have employed the following cointegration tests: (1) Engle-Granger (1987), (2) Johansen (1995) and (3) Johansen et al. (2000) with breaks. The first one is residuals

\footnotetext{
2 Exploiting both dimensions (time series and cross section) was problematic as the panel is unbalanced, the observations are infrequent and there are numerous zeroes for individual countries. As a result we could only aggregate the data given that the panel is unbalanced and panel cointegration not possible.

${ }^{3}$ Our results remain qualitatively similar when we consider mean European unemployment instead of weighted unemployment.

${ }^{4}$ The literature on unit roots is voluminous and one can argue one way or the other. In our case we did not make any a priori assumption about the stationarity of the series and followed the "let the data talk" approach since the emphasis of this note is on the long run coefficient. We have also considered both the logistic transformation (see Wallis (1987) and Farmer (2015)) and the literature for unit roots for bounded variables (see Carrion-i-Silvestre and Gadea (2013)).
} 
based, (2) and (3) are based on a VECM ${ }^{5}$. The results are presented in Table 1. They reveal that there is a long-run relationship between the extreme right share of the votes and unemployment for the period 1900-2013 (three tests point towards cointegration). The evidence for the other cases (unemployment with extreme or redical right and unemployment with extreme or radical left) is weaker and we get evidence for cointegration only when we allow for break (in 1933).

To explore the long run relationship between far right and radical left (see Bustikova 2014), we have also considered cointegration tests (2) and (3) for examining the long run relationship between far right, extreme left and unemployment (Table 3). The latter will examine the long-term codependence between far right and extreme left. When breaks were allowed a cointegrating relationship emerges between far right, extreme left and the unemployment rate.

The next step is to estimate the long-run coefficient(s). We have employed FMOLS (Fully Modified OLS), DOLS (Dynamic OLS) and CCR (Canonical Cointegrating Regression) (for more see Phillips and Hansen 1990, Saikkonen 1992, and Stock and Watson 1993 and Park 1992). The results are presented in Tables 2 and 4. The longrun coefficient for the first pair (extreme right and unemployment) is 1.37 on average, implying that a $1 \%$ increase in the European unemployment leads to a $1.37 \%$ rise in the far-right proportion of votes. The long-run coefficient for the other groups are either significantly lower ( 0.81 for the extreme and 0.55 for the radical right) or insignificant (extreme left and radical left). When we consider simultaneously far right, extreme left and unemployment we were getting evidence in favor of cointegration only in one case (see Table 3) and the corresponding long-run coefficients are appearing in table 4 that reflect the long run positive effect of both extreme left and unemployment on the far right.

\section{Conclusions}

We examined the long run relationship between the European unemployment rate and the share of votes of parties on the extreme of the political spectrum (extreme left and extreme right). We compile unique data that spans from 1900 to 2013 for 31 European countries. A long run relationship between extreme right and unemployment indicates that a $1 \%$ increase in the European unemployment is associated with $1.37 \%(0.81 \%)$ increase in the share of the vote of the far (extreme) right. Finally, we also find that both the extreme left and the unemployment rate

5 Hansen and Seo (2002) test for two-regime threshold cointegration in vector error-correction models. We focus on the long run and account for breaks rather than a model with two regimes. 
(jointly affect in the long-run the far-right share of the vote. A $1 \%$ rise in unemployment or in radical right vote share contributes to the far-right vote share, in the long run, $0.89 \%$ and $0.91 \%$ respectively (on average). 


\section{References}

Arzheimer, K. \& E. Carter. 2006. "Political Opportunity Structures and Right-Wing Extremist Party Success," European Journal of Political Research 45:419-443.

Arzheimer, K. 2009. "Contextual Factors and the Extreme Right Vote in Western Europe, 1980-2002," American Journal of Political Science 53:259-275.

Bustikova, L. 2014. "Revenge of the Radical Right" Comparative Political Studies 47:1-28.

Carrion-i-Silvestre, J. L. \& Gadea, M. D., 2013. "GLS-based unit root tests for bounded processes," Economics Letters, 120:184-187.

Eichengreen, B., and T. J Hatton (1988). "Interwar Unemployment in International Perspective: An Overview," in Eichengreen, Barry, and T. J Hatton (Eds), Interwar Unemployment in International Perspective, Dordrecht, Springer Netherlands.

Engle, R. F., and C. W. J. Granger (1987). "Co-integration and Error Correction: Representation, Estimation, and Testing," Econometrica, 55:251-276.

Farmer, R., (2015), The Stock Market Crash Really Did Cause the Great Recession, Oxford Bulletin of Economics and Statistics, 77:617-633.

Funke, M. and Schularick, M. \& Trebesch, C., 2016. "Going to extremes: Politics after financial crises, 1870-2014," European Economic Review, 88:227-260.

Georgiadou, V., Rori, L., \& Roumanias, C. (2018). Mapping the European far right in the 21st century: A meso-level analysis. Electoral Studies, 54, 103-115.

Golder, M. 2003. "Explaining Variation In The Success Of Extreme Right Parties In Western Europe," Comparative Political Studies 36(4): 432-466.

Hansen, B. E., \& Seo, B. (2002). Testing for two-regime threshold cointegration in vector error-correction models. Journal of Econometrics, 110(2), 293-318.

Ignazi, P. 2002. The Extreme Right: Defining the Object and Assessing the Causes. In Shadows Over Europe: The Development and Impact of the Extreme Right in Western Europe, ed. M. Schain, A. Zolberg \& P. Hossay. New York: Palgrave 22-38.

Johansen, S., Mosconi, R. and Nielsen, B. (2000). Cointegration analysis in the presence of structural breaks in the deterministic trend, Econometrics Journal3:216-249.

Johansen, S. (1995). Likelihood-based Inference in Cointegrated Vector Autoregressive Models, Oxford: Oxford University Press.

Mackie, T. T. and Richard R. (1991). The International Almanac of Electoral History, 3rd Ed., Hampshire: Macmillan.

March, L. (2011). Radical Left Parties in Europe, London: Routledge.

Matakos, K. and Xefteris, D., Economic Insecurity and Political Stability: A Case for GrowthTargeting Systemic Vote (2017). Available at http://dx.doi.org/10.2139/ssrn.2567834 
Minkenberg, M. (2013). The European Radical Right and Xenophobia in West and East: Trends, Patterns and Challenges. In Right-wing extremism in Europe country analyses, counter-strategies and labor-market oriented exit strategies, ed. R. Melzer \& S. Serafin. Berlin.

Mitchell, B. (2007). International Historical Statistics: Europe 1750-2005, 5th E., Hampshire: Palgrave Macmillan.

Mudde, C. 2007. Populist Radical Right Parties in Europe. Cambridge: Cambridge University Press.

Nohlen, D. and P. Stöver (2010). Elections in Europe: A Data Handbook, Baden-Baden: Nomos.

Park, J. Y. (1992). “Canonical Cointegrating Regressions,” Econometrica, 60:119-143.

Payne, S. G. 1995. A History of Fascism 1914-1945, Wisconsin: The University of Wisconsin Press.

Phillips, P. C. B. and B. E. Hansen (1990). "Statistical Inference in Instrumental Variables Regression with I(1) Processes," Review of Economics Studies, 57:99-125.

Saikkonen, P. (1992). "Estimation and Testing of Cointegrated Systems by an Autoregressive Approximation," Econometric Theory, 8:1-27.

Stock, J. H. and M. Watson (1993). "A Simple Estimator Of Cointegrating Vectors In Higher Order Integrated Systems,” Econometrica, 61:783-820.

Wallis, K.F. (1987) Time series analysis of bounded economic variables. Journal of Time Series Analysis 8:115-123. 
Figure 1

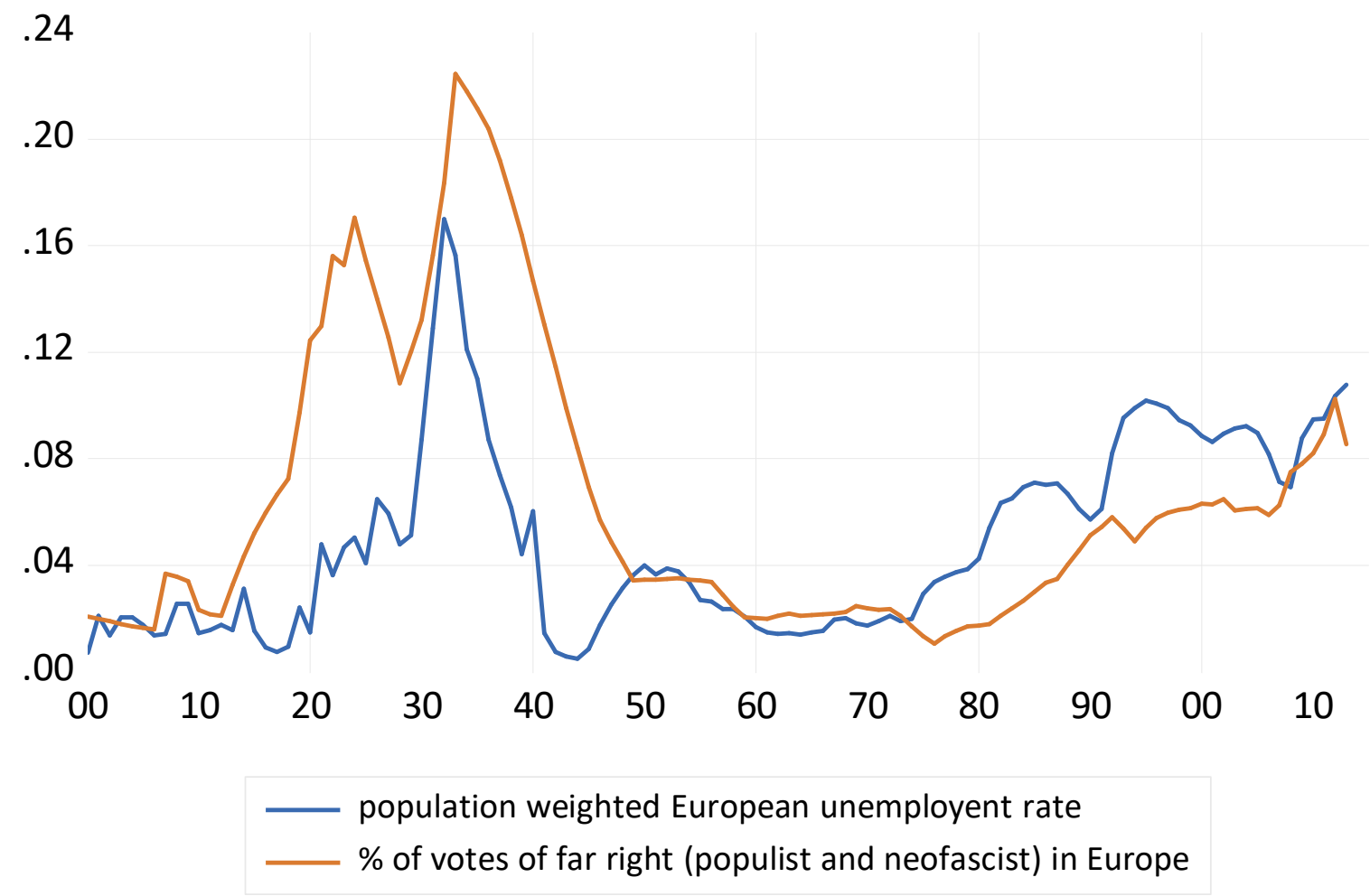


Table 1: Cointegration tests ( $p$-values only)

\begin{tabular}{|c|c|c|c|c|c|}
\hline Cointegration test & Far Right - Unemployment & Extreme Right - Unemployment & Populist Right - Unemployment & Extrreme Left - Unemployment & Radical Left - Unemployment \\
\hline Engle-Granger & 0.000 & 0.002 & 0.056 & 0.095 & 0.228 \\
\hline \multicolumn{6}{|l|}{ Johansen - Trace } \\
\hline None & 0.064 & 0.4821 & 0.289 & 0.846 & 0.716 \\
\hline At most one & 0.500 & 0.4904 & 0.812 & 0.672 & 0.480 \\
\hline \multicolumn{6}{|c|}{ Johansen with break in 1933} \\
\hline None & 0.008 & 0.000 & 0.016 & 0.000 & 0.010 \\
\hline At most one & 0.0785 & 0.116 & 0.762 & 0.937 & 0.316 \\
\hline
\end{tabular}

Note: We have employed the following cointegration tests: (1) Engle-Granger (1987), (2) Johansen (1995), (3) Johansen et al. (2000) with breaks.

Table 2: Long run coefficient from DOLS, FMOLS and Canonical Cointegration regression

\begin{tabular}{|c|c|c|c|c|c|}
\hline & Long-run Coefficient & & & & \\
\hline & Far Right - Unemployment & Extreme Right - Unemployment & Populist Right - Unemployment & Extrreme Left - Unemployment & Radical Left - Unemployment \\
\hline FMOLS & $1.37 \mathrm{t}$-stat 8.25 & $0.81 \mathrm{t}-\mathrm{s}$ tat 6.22 & 0.55 t-stat 4.38 & $0.13 \mathrm{t}$-stat 1.04 & -0.16 t-stat -1.25 \\
\hline DOLS & 1.38 t-stat 7.89 & 0.84 t-stat 5.92 & 0.53 t-stat 3.97 & 0.13 t-stat 0.95 & -0.15 t-stat -1.04 \\
\hline CCR & $1.36 \mathrm{t}$-stat 8.36 & $0.81 \mathrm{t}$-stat 6.24 & 0.55 t-stat 4.41 & $0.13 \mathrm{t}$-stat 1.04 & -0.16 t-stat -1.24 \\
\hline
\end{tabular}

Note: These are long-run coefficients from regressions of the type: Percentage of Far Right Votes $=\alpha+\beta^{*}$ Unemploment Rate+error. 
Table 3: Cointegration tests for (i) Far right - Extreme Left and unemployment and (ii) Neo-fascist Right - Extreme Left and Unemployment (only $p$-values)

\begin{tabular}{|l|c|c|}
\hline & Far Right - Extreme Left - Unemployment & Extreme Right - Extreme Left- Unemployment \\
\hline Johansen - Trace & & 0.32 \\
\hline None & 0.5471 & 0.5571 \\
\hline At most one & 0.3415 & 0.5564 \\
\hline At most two & & 0.6235 \\
\hline Johansen with breaks in 1921 and 1933 & 0.03 & 0.2456 \\
\hline None & 0.16 & 0.3181 \\
\hline At most one & 0.56 & 0.2828 \\
\hline At most two & & \\
\hline
\end{tabular}

Table 4: Long run coefficients for case (i) Far right - Extreme Left and unemployment

\begin{tabular}{|c|c|c|c|}
\hline & DOLS & FMOLS & CC \\
\hline Dependent variable & Far Right & Far Right & Far Right \\
\hline Constant & -0.011 & -0.013 & -0.013 \\
\hline & -0.652 & -0.782 & -0.794 \\
\hline Extreme Left & $0.913^{* * *}$ & $0.915^{* * *}$ & $0.911^{* * *}$ \\
\hline & 2.810 & 2.897 & 2.937 \\
\hline Unemployment rate & $0.866^{* * *}$ & $0.903^{* * *}$ & $0.904^{* * *}$ \\
\hline & 4.069 & 4.594 & 4.629 \\
\hline
\end{tabular}




\section{ONLINE APPENDIX}

\section{Data}

The data on national European Elections (1900-1990) were obtained by Mackie and Rose (1995) and Nohlen and Stöver (2010). Data for 1990-2012 were obtained from the European Elections Database (EED). ${ }^{6}$ National electoral data were aggregated at the European level as follows: for each country, we obtained far-right votes and valid votes in non-election years by linear interpolation. The votes were then aggregated to European levels. Far-right vote shares were obtained by calculating the ratio of total European far-right votes to total European valid votes for each year.

Country-level data on unemployment 1900-1960 were obtained from Mitchell (2007) where available. Additional prewar unemployment data were obtained from Eichengreen and Hatton (1988). Postwar unemployment data were taken from the UN Economic Reports 1949-1960. Unemployment data 1960-2012 were taken from AMECO macro-economic database. Both populations weighted and average European unemployment was then computed for each year in the sample (the results for the latter available on request).

To identify and classify populist radical right and extreme right parties we proceeded as follows: For the period 1900-1945, we followed Payne (1995). For post-war far-right parties, we followed the classifications of Ignazi (2002), Golder (2003), Minkenberg (2013) and Mudde (2007). Our classification of extreme left parties follows March (2011).

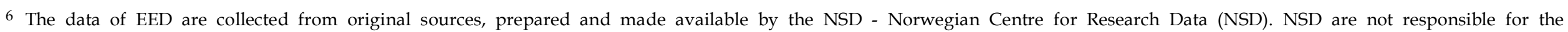
analyses/interpretation of the data presented here. 
Table 5: List of countries and percentage of sample

\begin{tabular}{|c|c|c|c|}
\hline & Country code & Obs. & $\%$ of sample \\
\hline 1 & Austria & 107 & 4.51 \\
\hline 2 & Belgium & 111 & 4.67 \\
\hline 3 & Bulgaria & 19 & 0.8 \\
\hline 4 & Croatia & 22 & 0.93 \\
\hline 5 & Cyprus & 21 & 0.88 \\
\hline 6 & Czech Republic & 91 & 3.83 \\
\hline 7 & Denmark & 114 & 4.8 \\
\hline 8 & Estonia & 20 & 0.84 \\
\hline 9 & Finland & 105 & 4.42 \\
\hline 10 & France & 103 & 4.34 \\
\hline 11 & Germany & 143 & 6.02 \\
\hline 12 & Greece & 87 & 3.66 \\
\hline 13 & Hungary & 95 & 4 \\
\hline 14 & Iceland & 92 & 3.87 \\
\hline 15 & Ireland & 90 & 3.79 \\
\hline 16 & Italy & 119 & 5.01 \\
\hline 17 & Latvia & 19 & 0.8 \\
\hline 18 & Lithuania & 17 & 0.72 \\
\hline 19 & Luxembourg & 20 & 0.84 \\
\hline 20 & Malta & 67 & 2.82 \\
\hline 21 & Netherlands & 125 & 5.26 \\
\hline 22 & Norway & 132 & 5.56 \\
\hline 23 & Poland & 89 & 3.75 \\
\hline 24 & Portugal & 37 & 1.56 \\
\hline 25 & Romania & 85 & 3.58 \\
\hline 26 & Slovakia & 21 & 0.88 \\
\hline 27 & Slovenia & 17 & 0.72 \\
\hline 28 & Spain & 79 & 3.33 \\
\hline 29 & Sweden & 124 & 5.22 \\
\hline 30 & Switzerland & 116 & 4.88 \\
\hline \multirow[t]{2}{*}{31} & United Kingdom & 88 & 3.71 \\
\hline & Total & 2,375 & 100 \\
\hline
\end{tabular}


Table 6: Unit root tests

\begin{tabular}{|c|c|c|c|c|c|c|}
\hline & ADF $p$-value & Phillips-Perron $p$-value & ADF with break $p$-value & Break Date & Unit Root test with break & Date \\
\hline Far Right & 0.107 & 0.409 & 0.270 & 1933 & -2.201 \\
\hline Extreme Right & 0.114 & 0.319 & 0.181 & 1933 & -2.3778 \\
\hline Populist Right & 0.141 & 0.276 & 0.788 & 1936 & -2.441 \\
\hline Extreme left & 0.504 & 0.443 & 0.901 & 1987 & -0.531 \\
\hline Radical Left & 0.035 & 0.060 & 0.100 & 1907 & -2.567 \\
\hline Unemployment rate & 0.122 & 0.106 & 0.676 & 1980 & -2.059 \\
\hline & & & Vogelsang (1993) p-values & Critical Value from (Lanne et al. 2002) -3.43 \\
\hline
\end{tabular}

Note: Data from 1900 to 2013. The Breakpoint Unit Root test involves breakpoint selection with DickeyFuller min- $t$ and innovation outlier. Lag length based on the SC. Unit root with break refers to the test proposed in Lanne, M., Lutkepohl, H. and Saikkonen, P. (2002), Comparison of unit root tests for time series with level shifts. Journal of Time Series Analysis, 23: 667-685.

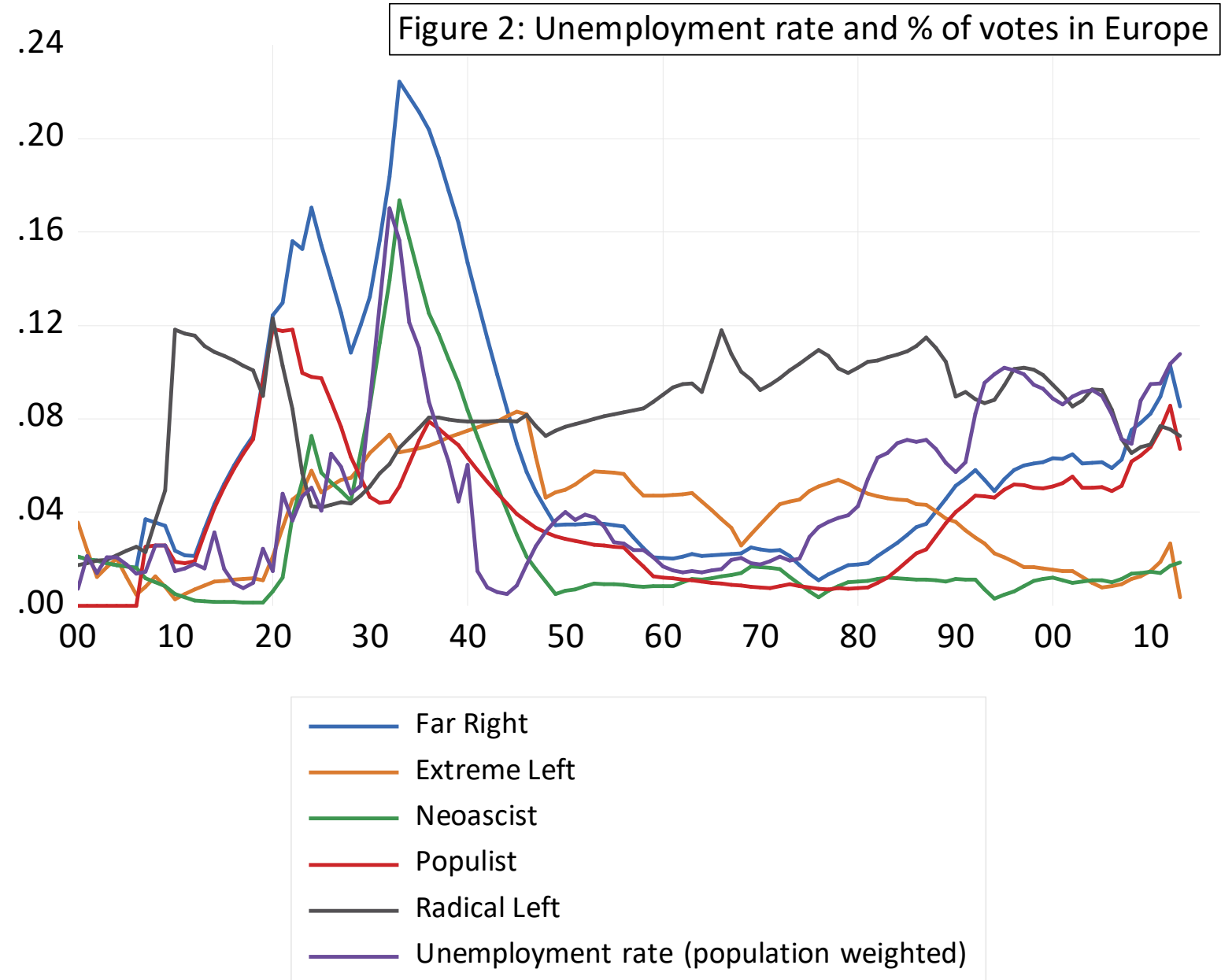


Table 7: Unit root tests for the logistic transformation of the variables (see Wallis 1987 and Farmer 2015)

\begin{tabular}{|c|c|c|}
\hline logistic transformation of & ADF $p$-value & Phillips-Perron $p$-value \\
\hline Far Right & 0.4291 & 0.75 \\
\hline Extreme Right & 0.04 & 0.20 \\
\hline Populist Right & 0.40 & 0.64 \\
\hline Extreme left & 0.71 & 0.75 \\
\hline Radical Left & 0.00 & 0.01 \\
\hline Unemployment rate & 0.14 & 0.13 \\
\hline
\end{tabular}

